разнообразные явления в современной мировой культуре, определять особенности ее бытия. Всё это наводит на мысль о необходимости коррекции трактовки сущности и функций культур, принадлежащих к указанному метапериоду, и открывает перспективу в исследовании особенностей бытия современной культуры, ее хронотопа.

\section{Список литературы}

1. Ясперс К. Смысл и назначение истории. - М.: Политиздат, 1991.

2. Радииг С.И. История древнегреческой литературы: учеб. для филол. фак. ун-тов. - М.: Высшая школа, 1982.

3. Татаркевич В. Античная эстетика. - М.: Искусство, 1977.

4. Бычков В.В. Малая история византийской эстетики. Киев: Путь к истине, 1991.

5. Опанасюк 0.П. Художній образ: структурна феноменологія і типологія форм. Монографія. - Дрогобич: Коло, 2004.

6. Левяш И.Я. Культурология. - М.: Айрис-пресс, 2004.

7. Теория культуры: разнообразие подходов и возможности их интеграции / под ред. Ю.М. Резника. - М.: Научно-политическая книга, 2012.

8. Опанасюк А.П. На пути к интегральной культурологии: структурно-динамическая метапарадигма культуры // Научная дискуссия: вопросы филологии, искусствоведения и куль- турологии: Материалы XI международной заочной научнопрактической конференции. Часть I (30.04.2013 г.). - М.: Изд-во «Международный центр науки и образования», 2013.

9. Опанасюк О.П. До питання визначення оптимальних закономірностей структурального буття культур // Українське мистецтвознавство. Вип. 9. - Киев: ІМФЕ, 2009.

10. Блаватская Е.П. Разоблаченная Изида. Ключ к тайнам древней и современной науки и теологии. Т. 1. Наука. - М.: Издво Ассоциации Духовного Единения «Золотой век», 1993.

11. Блаватская Е.П. Тайная доктрина: синтез науки, религии и философии. В 2 т., 4 кн. Т. 1, кн. 2. Космогенезис / пер. с англ. Е.И. Рерих; подгот. текста В.Э. Жигота. - Мн.: Маст. літ., 1993.

12. Блаватская Е.П. Теософский словарь. - М.: Изд-во Ассоциации Духовного Единения «Золотой век», 1994.

13. Брейден Г. 2012: Время великих перемен / пер. с англ. Е. Беловой. - М.: Эксмо, 2010.

14. Бургон Т.Г. Свет Египта. - M.: REFL-book, 1994.

15. Величко Ф., Мансуров В. На пороге эры Водолея [Электронный ресурс]. - Режим доступа: http://вседуховное. рф/ величко-ф-мансуров-в-на пороге-эры-вод

16. Титов А. Начало Эры Водолея // Новая эпоха. 1998. — № 1 (16) [Электронный ресурс]. - Режим доступа: http://www. newepoch.ru/journals/16-7/titov_vodolei.html

17. Блаватская Е.П. Скрижали кармы / пер. с англ. К.Ю. Бурмистрова. - М.: МЦФ, 1995.

\title{
М.Я. САРАФ
}

\section{ОПЫТ ПОСТРОЕНИЯ ТРЕХМЕРНОЙ МОДЕЛИ КУЛЬТУРНОГО ПРОСТРАНСТВА}

Автор исходит из понимания культуры как способа бытия человека. На этом основании выделяются пять типообразующих факторов культуры: способ отношения к природе, способ деятельности, способ сообщности, способ мышления и способ понимания. Показано, как меняются их содержание и структура в зависимости от конкретно-исторических условий существования социума - доцивилизационного, цивилизационного и постцивилизационного, что автор представляет как двухмерную модель культурного пространства. Третье измерение - это ценностно-смысловая координата, которая показывает социокультурное содержание ответа на вопрос «кто есть человек» в разных типах культур.

Ключевые слова: способ отношения к природе, способ деятельности, способ сообщности, способ мышления, способ понимания координата содержания историко-культурного процесса, координата эволюционно-историческая, координата ценностно-смысловая.

Д ля построения модели культурного пространства основополагающим будет понимание культуры как способа бытия человека, представленного в соального бытия. Такой подход дает возможность принять выражение «способ бытия» в качестве типологического понятия и на этом основании попытаться выявить те составляющие, структурно-функциональной связью которых определяется конкретное содержание исторических типов культуры и их многообразие.
Такие составляющие можно представить в понятиях «способ отношения к природе», «способ деятельности», «способ сообщности», «способ мышления» и «способ понимания» ${ }^{1}$.

Способ отношения человека к природе, или способ потребления ресурсов природы, - первый и важнейший

\footnotetext{
${ }^{1}$ Данные типообразующие факторы описаны и определены в книге автора статьи «0пыт типологии культуры» [1]. В настоящей статье представлена их краткая характеристика.
} 
типообразующий фактор культуры, поскольку деятельность человека есть, прежде всего, преобразование вещества природы. Исходя из естественно-исторического эволюционного понимания возникновения и развития человечества, можно с достаточной ясностью различать три основных типа в способе отношения человека к природе: доцивилизационный (слияние, или единство с природой), цивилизационный (преодоление природы, производящее хозяйствование) и постцивилизационный (воспроизводящее хозяйствование, экосистемность).

Понятие способ деятельности употребляется здесь для обозначения типообразующего фактора культуры, выражающего объем способностей и умений человека, которыми он преобразует вещество природы и которые не просто обеспечивают его жизнедеятельность, но являются необходимыми и достаточными для признания сообществом индивида в качестве человека. Иначе говоря, этим фактором определяется, что должен уметь делать человек в данном конкретно-историческом сообществе, чтобы быть признанным в качестве его сочлена. При всем многообразии исторически существовавших культур способ деятельности может быть достаточно четко типологизирован; он, разумеется, теснейшим образом связан со способом отношения к природе, возникает на его основе и определяет им свое содержание.

Следующий типообразущий фактор культуры сnособ сообщности. Именно этот фактор определяет непосредственно способ признания, определяет ответ на основной вопрос культуры: кто есть человек, кого считать человеком.

Способ мышления - это способ осознания человеком своего отношения к миру, способ получения и обработки информации, новых знаний, способ, которым образуются и выражаются мыслительные связи. Так, синкретическому способу деятельности и кровнородственному способу сообщности исторически соответствует магический, мифологический способ мышления. Основной принцип мышления здесь - антропологизация внешнего мира и оприроживание собственного внутреннего мира и действия.

Последний из выделяемых типологических факторов культуры - это способ понимания, конечно же, теснейшим образом связанный со способом мышления, будучи все-таки отличным от него. Что значило для человека античной культуры понять мир, свое место в нем и т. п.? Понять - значило указать границы, пределы, область существования, меру. Механизм понимания здесь - мышление по аналогии. В других типах культуры понимание строится по другим основаниям.

Указанные типологические характеристики культуры инвариантны. Они присутствуют в каждом типе культуры, но их развитости и способы взаимосвязи и взаимодействия весьма различны, многообразны. В определенных исторических условиях тот или иной типообразующий фактор может приобретать доминирующее значение, задавать культуре определенную направленность, служить как бы ее вектором.
Взаимосвязь и взаимозависимость представленных системообразующих факторов культуры достаточно хорошо различимы даже в предварительном их рассмотрении. Эта взаимосвязь имеет системный характер, то есть все указанные факторы выступают и во взаимных причинно-следственных связях таким образом, что изменение одного из них влечет за собой изменение и всех других и приводит, в конечном счете, к изменению типа культуры.

Для начала построим схему, где базовой координатой будет последовательность предложенных пяти факторов (способ отношения к природе и т. д.), которыми задается содержание историко-культурного процесса. Схема развертывается в соответствующие им исторически сменяемые методы и формы актуализации типов культуры. Это - координата эволюционно-историческая (табл. 1).

Положение человека в природе и отношение человека к природе, как было отмечено выше, в самой общей историко-логической схеме имеет несколько этапов. Начальный этап - неотделенность человека от природы, единство с нею, существующее на основе собирательства. Это время сопряжено с синкретическим способом деятельности (а синкретическая деятельность формирует, в свою очередь, и соответствующее отношение к природе), возможным и необходимым только в условиях весьма ограниченного ресурса воспроизводства человека, каким является прежде всего и по преимуществу ресурс природный - географический и биологический, в том числе количество людей в племени. Поэтому человек осознается почти исключительно в системе кровнородственных связей. Отсюда антропоморфный, мифологический способ мышления, связывающий человека и внешний мир в чувственно-непосредственных жизненно практических родственных отношениях.

При этом единый способ отношения к природе и единый способ деятельности формируют и единое племенное сознание, где определяющим способом понимания, то есть ориентации в природном и антропном пространстве, была аналогия, усваиваемая через чувственную наглядность олицетворенных природных сил.

Следующий этап — производительное хозяйствование: от первых форм скотоводства и земледелия до промышленных научно-технических революций Нового и Новейшего времени. Это этап цивилизационных условий развития культуры.

Во второй половине XX века начинается переходный критический период этого этапа, обусловленный исчерпанием природного ресурса и угрожающим культуре гомогенным давлением человека на природу. Такое давление получило геологический, а в чем-то и космический масштаб, и продолжает нарастать, ибо способ деятельности и способ мышления (по преимуществу утилитаристские и физикалистские) принципиально не изменились.

XXI век открывается теми же надеждами, которые составляли содержание гуманистических утопий и социалистических учений, - надеждами на торжество разума или благоразумия, надеждами на прогресс науки или 


\begin{tabular}{|c|c|c|c|c|}
\hline $\begin{array}{c}\text { Способ отношения } \\
\text { к природе }\end{array}$ & $\begin{array}{c}\text { Способ } \\
\text { деятельности }\end{array}$ & $\begin{array}{c}\text { Способ } \\
\text { сообщности }\end{array}$ & $\begin{array}{c}\text { Способ } \\
\text { мышления }\end{array}$ & $\begin{array}{c}\text { Способ } \\
\text { понимания }\end{array}$ \\
\hline $\begin{array}{l}\text { Доцивилизационный: } \\
\text { единство, слияние }\end{array}$ & Синкретический & $\begin{array}{l}\text { Род, племя } \\
\text { (кровно- } \\
\text { родственная связь) }\end{array}$ & $\begin{array}{l}\text { Мифологический, } \\
\text { магический }\end{array}$ & $\begin{array}{l}\text { Олицетворение, } \\
\text { антропоаналогия }\end{array}$ \\
\hline \multirow{2}{*}{$\begin{array}{l}\text { Цивилизационный: } \\
\text { преодоление } \\
\text { (производительное } \\
\text { хозяйствование) }\end{array}$} & $\begin{array}{l}\text { Социально- } \\
\text { специализированный }\end{array}$ & $\begin{array}{l}\text { Сословие } \\
\text { (имущественные } \\
\text { отношения и ценз) }\end{array}$ & $\begin{array}{l}\text { Рационально- } \\
\text { религиозный }\end{array}$ & Указание пределов \\
\hline & Ремесленно-цеховой & $\begin{array}{l}\text { Община (патронально- } \\
\text { экономическая связь) }\end{array}$ & $\begin{array}{l}\text { Иррационально- } \\
\text { религиозный }\end{array}$ & $\begin{array}{l}\text { Отношение } \\
\text { к сверхсущему }\end{array}$ \\
\hline \multirow{2}{*}{ Переходный } & Профессиональный & $\begin{array}{l}\text { Нация } \\
\text { (культурно- } \\
\text { экономическое } \\
\text { единство) }\end{array}$ & $\begin{array}{l}\text { Рационально- } \\
\text { логический }\end{array}$ & $\begin{array}{l}\text { Аргументация, } \\
\text { выводное } \\
\text { объяснение }\end{array}$ \\
\hline & & $\begin{array}{l}\text { Элиты, группировки, } \\
\text { масса }\end{array}$ & $\begin{array}{l}\text { Чувственно- } \\
\text { образный }\end{array}$ & $\begin{array}{l}\text { Переживание че- } \\
\text { рез потребление }\end{array}$ \\
\hline $\begin{array}{l}\text { Постцивилизационный } \\
\text { (перспектива): } \\
\text { гармонический } \\
\text { (воссоздающее } \\
\text { хозяйствование) }\end{array}$ & $\begin{array}{l}\text { Специализированно- } \\
\text { универсальный }\end{array}$ & $\begin{array}{l}\text { Сообщество } \\
\text { сотрудничества }\end{array}$ & $\begin{array}{l}\text { Понятийно-об- } \\
\text { разный }\end{array}$ & Системное \\
\hline
\end{tabular}

же чудесную силу просвещения, хотя, конечно, надежды эти не столь энтузиастичны. Но при этом мировое общественное сознание уже привыкает к мысли, что будущее человечества, то есть культуры, возможно только при кардинальном изменении отношения человека к природе.

Древние цивилизации начинаются с социальной дифференциации в деятельности, прежде всего производительной, а поскольку статус человека определяется уже не природной, родственной связью, но отношением к вещам как объекту собственности, то скоро индивид оказывается и осознается в собственнических отношениях. Насколько он сам попадает в имущественную зависимость и становится объектом собственности, настолько он причисляется к вещам и тем самым утрачивает статус человека, и даже не признается таковым. Субъектом социальных отношений является только человек свободный, что означает владеть имуществом, распоряжаться и управлять им.

Социальное разделение труда и социальная организация жизни требуют институтов управления, третейского суда, регулярной воинской службы, образования и т. д., что отводит традицию и обычай как жизнеобеспечивающие факторы на второй план. На первый же выходит письменность, грамотность как ведущий способ передачи и хранения социальной информации, необходимой для общественного воспроизводства. Вместе с этим принципиально меняется и способ мышления - от образного и антропоморфного к религиозно-рациональному, с которым формируются и научное познание, и художественное творчество как специализированные области деятельности. Способом же понимания становится количественная и качественная упорядоченность, соотнесенность вещного бытия, помещение его в пределах, охватываемых мышлением. Это сущностные характеристики античной культуры, завершившейся с распадом рабовладения.

Новый тип культуры вырастает из того, что способ деятельности и способ сообщности оказываются в новой, сильной зависимости от предмета трудовой деятельности, от ее довольно жесткого ограничения местом рождения и сословной принадлежностью. С одной стороны, теперь каждый индивид признается человеком, с другой - это признание относительно. Но вещно-предметный критерий определения статуса «подлинного» человека сменяется признанием приоритета духовного начала. Локально заданное рационально-религиозное мышление уступает как бы общечеловеческому (с точки зрения, разумеется, адептов веры) иррационально-религиозному. А способ понимания, как мы уже видели, выражается отношением к божественному Абсолюту как сверхприродной причине сущего. Отсюда и доминантное направление на комментирование и поучение в сфере науки, искусства и образования.

Развитие промышленного производства и демократического политического устройства общества с их стремительно расширяющейся и углубляющейся специализацией порождает четкую социальную стратификацию и самый 
эффективный способ деятельности - профессиональный, требующий регулярного систематического образования, рационально-логического мышления, главной целью которого становится теперь инновация, выработка новых технических, научных, художественных, политических идей, постановка и решение новых, творческих задач. Доминантным способом понимания становится рациональное объяснение, аргументация и доказательство.

Теперь обретение индивидом статуса и ценности человека в значительной мере зависит от успешности его профессиональной деятельности. Данное обстоятельство определяет ставшую актуальной потребность развития индивида в личность, в активный и творческий субъект деятельности. Причем эта потребность приобретает общесоциальный масштаб, становится программной целью всей системы воспитания и образования, личность провозглашается высшей ценностью, ее приоритетность даже противопоставляется государству. Человек как личность осознается и признается главным содержанием той линии развития, которая со времен Возрождения получила название гуманизма.

Однако на протяжении XX века соотношение типообразующих факторов изменилось настолько, что по сути стало утрачивать свою системность в силу того, что разная скорость движения и развития каждого из них и различная степень интенсивности последствий такого развития для всей системы культуры привели ее в состояние довольно глубокого расстройства, обусловили появление определенных трудностей в процессе ее воспроизводства.

Прежде всего, как уже было отмечено, противоречие между обществом и природой приняло характер антагонизма. Способы деятельности и сообщности в значительной мере утратили свою социально организующую, социально консолидирующую роль, их структура и их функции существенно изменились. Сообщества стали складываться на довольно эфемерной основе уровня доходов и меры потребления. Образовалась так называемая элита, как правило, весьма разнородная по своему составу (и социальному, и деятельностному, и образовательному) и космополитичная. Появился средний класс, крайне рыхлый, социально несвязанный и едва ли способный к каким-либо действиям в качестве сообщества. Но сформировались еще и другие сообщества, не стремящиеся выходить на свет, но ставшие в настоящее время едва ли не диктующими условия всем остальным - корпоративные (национальные и наднациональные, этнические, криминальные и пр.). Конечно, криминальные организации существовали всегда, но это были маргинальные сообщества в социуме, в настоящее время их масштаб стал панмировым, а деятельность сопоставима с деятельностью таких официальных структур, как государства и даже превосходит ее. Сообщества, за счет деятельности которых в действительности обеспечивается воспроизводство культуры, оказываются во все более зависимом положении и все менее структурно организованы.

Разумеется, в таком мире рационально-логический способ мышления сильно теснится фрагментарно-эклек- тическим, чувственно-образным, а способ понимания все более и более сопрягается с непосредственным чувственно-вещным потреблением и переживанием. Вопрос «кто человек» решается теперь не столько в сфере деятельности, но преимущественно в сфере распределения и потребления. В качестве всемирной рейтинговой системы все более выступают средства массовой информации, и одним из наиболее показательных критериев того, что человек «вышел в люди», становится успешность и популярность.

Выход из кризиса - в переходе к воспроизводящему хозяйствованию, в гармоническом отношении человека к природе, что, естественно, требует нового специализированно-универсального способа деятельности, нового способа сообщности, действующего в интересах всего человечества. Таким может быть только мировое сообщество, международное сотрудничество для осуществления общих программ освоения и потребления природных ресурсов, регулирования количества населения и принципов расселения, образования и профессиональной подготовки. Движение в этом направлении так или иначе происходит и проявляет себя в деятельности авторитетных и ответственных международных организаций, таких как 0ОН, ЮНЕСКО, международные форумы и саммиты и т. п. Но это пока процессы довольно разрозненные, развивающиеся с большим трудом и настолько противоречиво, что нельзя быть уверенным в их исторической результативности.

Способ мышления и способ понимания, по логике наших рассуждений, должны приобрести универсальносистематический характер. Каждый индивид развивается в процессе воспитания, образования и социализации в человека универсального, который, конечно, формируется как личность, обладающая такой степенью развитости своих физических и интеллектуальных способностей и своей общественной сущности, что свободно владеет методологией деятельности и поэтому, применяя их по потребности, может достигать высших результатов в любой сфере общественного воспроизводства. Так преодолевается и ограниченность профессионализма при сохранении всех его преимуществ. Здесь не имеется в виду, что человек становится многостаночником швец, и жнец, и на дуде игрец. Речь идет о том, что новый тип культуры - это производство человека, подготовленного и способного к высшей результативности на любом поприще, человека, которому любое поприще доступно.

Это историческая перспектива культуры, если общий логический принцип построения предложенной типологической схемы соответствует объективной направленности общественного развития. Но способы и формы движения в этом направлении, как было замечено выше, или еще весьма слабо проявлены, или очень спорны, во всяком случае, встречают сильное сопротивление и не всегда прокладывают себе путь. Так что возможность этой перспективы пока довольно проблематична.

Построенная схема позволяет определять и те доминантные содержательные формы, в которых разные типы культуры себя осознают (табл. 2). Они могут быть 
0
0
5
5
5
5
5
0

\begin{tabular}{|c|c|c|c|c|c|c|}
\hline 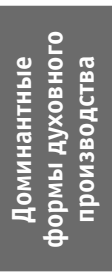 & 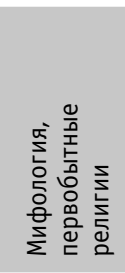 & 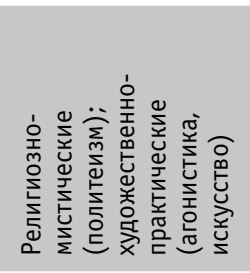 & 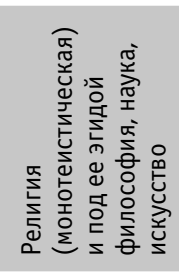 & 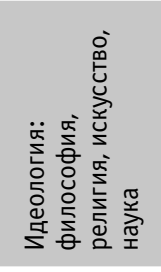 & & 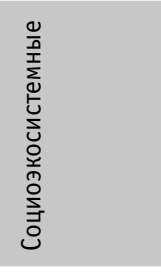 \\
\hline 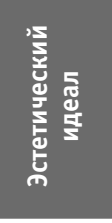 & 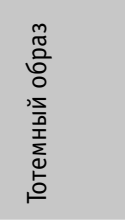 & 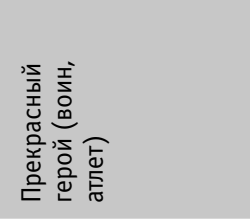 & 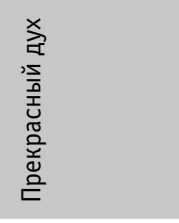 & 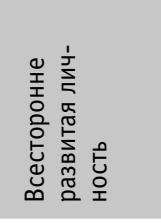 & 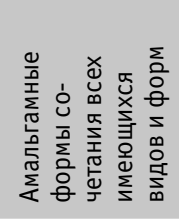 & 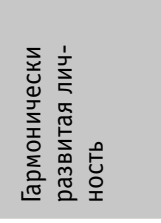 \\
\hline 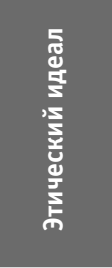 & 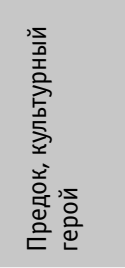 & 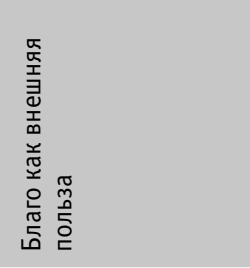 & 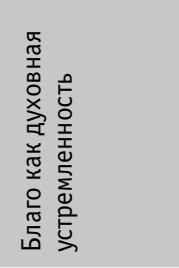 & 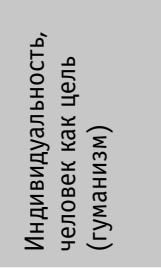 & 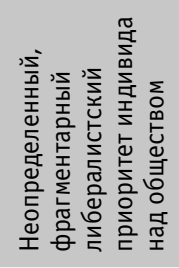 & 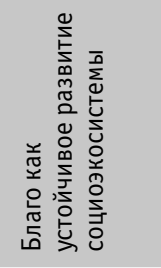 \\
\hline 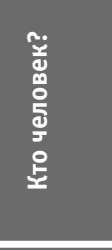 & 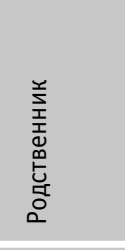 & 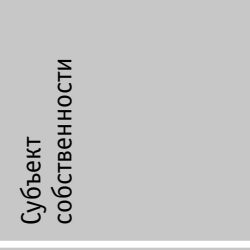 & 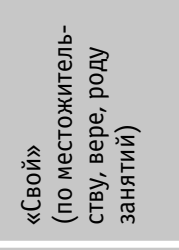 & 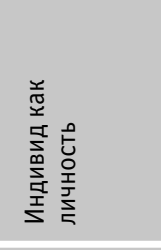 & 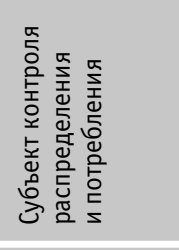 & 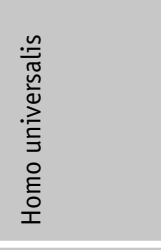 \\
\hline 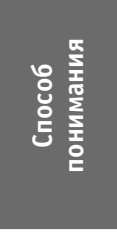 & 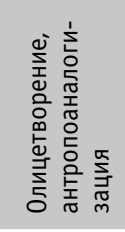 & 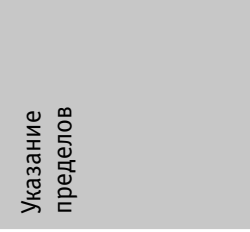 & 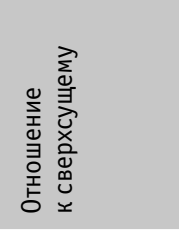 & 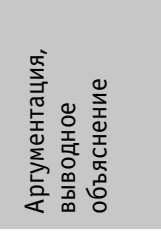 & 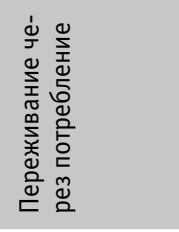 & 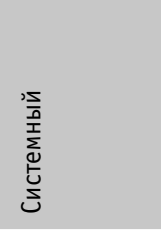 \\
\hline 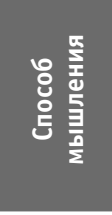 & 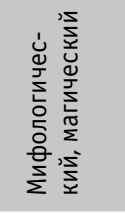 & 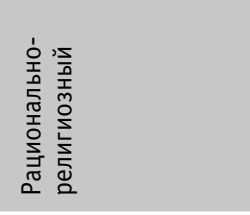 & 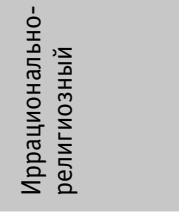 & 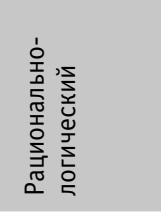 & 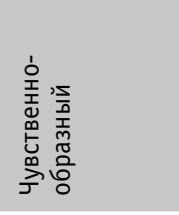 & 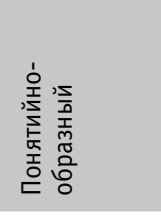 \\
\hline 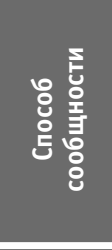 & 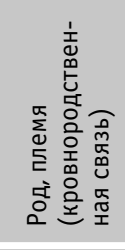 & 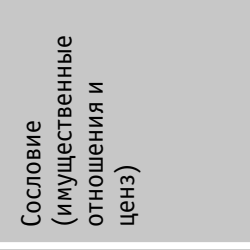 & 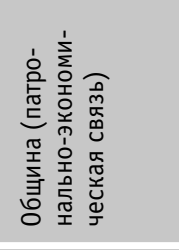 & 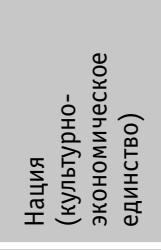 & 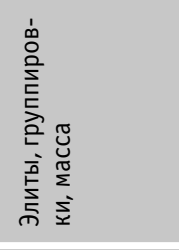 & 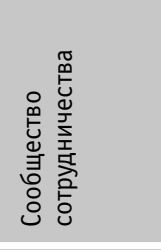 \\
\hline 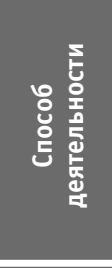 & 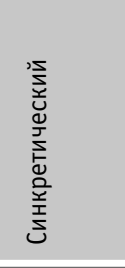 & 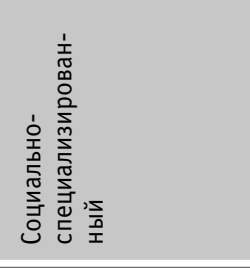 & 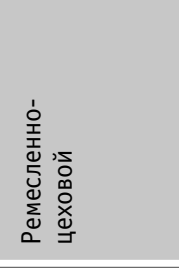 & 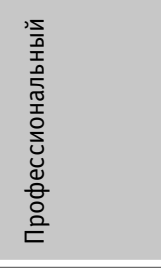 & & 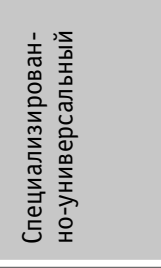 \\
\hline 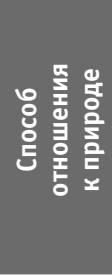 & 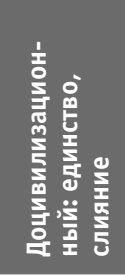 & 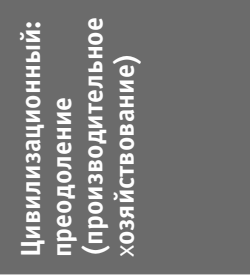 & & 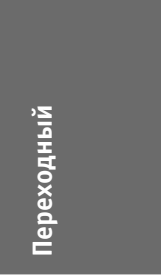 & & 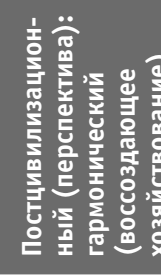 \\
\hline
\end{tabular}


представлены в качестве третьей координаты, размещенной за разделительной линией. Эту координату назовем ценностно-смысловой. Ее можно дополнять и расширять в зависимости от задач исследования культурных процессов. Например, можно ввести такие квалификаторы, как «способ образования», «общественный идеал», «герой времени». Такая развертка и представляет собой трехмерную модель пространства культуры, поскольку плоскость ценностно-смысловой координаты можно воспринимать как вертикальную.

Для доцивилизационного типа культуры (при относительной нерасчлененности человека и природы), где социальная связь тождественна связям кровнородственным, наиболее характерны синкретическая деятельность и синкретическое сознание, выражавшееся в мифологических формах и в формах первобытных религий: фетишизме, анимизме, магии, тотемизме. Племенная ментальность задана архетипами, и образ, по которому формируется и «возделывается» человек, представлен предками и соплеменниками, а в еще большей степени образом культурного героя мифов. Племенное сообщество замкнуто на себя и вполне самодостаточно. Поэтому такой тип культуры может воспроизводиться сколь угодно длительное время в совершенной идентичности, если нет значительного внешнего вмешательства или влияния. Это циклическое движение культуры, не осознающей себя и, следовательно, не знающей истории.

Следующий ряд зависимостей, являющий культурные типы цивилизаций (от древних до современности), вместе со специализацией деятельности показывает всё большее и большее возрастание интенсивности и специализации самосознания сообществ. Выход на первый план рационально-религиозного способа мышления порождает науку (от первофилософии до современной системы наук) и искусство (от эпоса до профессионального искусства нашего времени). Образ, по которому воспроизводится культура, теперь уже конструируется как общественный идеал, как образ совершенной социальной организации и как образ соответствующего ей «настоящего» человека. Важнейшими структурными частями общественного идеала становятся этический и эстетический идеалы. Собственно, этим условием задается вектор движения культуры, осознаваемая ею цель движения как развития. Впоследствии движение к этой цели будет понято как историческое движение и выражено в понятиях общественного и культурного прогресса.

Для античной культуры этический идеал (представление о добре, благе) связан с пользой, с достойными человека отношениями и пользованием вещами. Эстетический идеал также по большей части выражал вещественное бытие человека - пригодность вещи, пригодность человека для достойной деятельности. Отсюда - образ человека как образца, как героя и его вещественное художественное воплощение в «Каноне».

Конец античной культуры - это утрата приоритета для человеческого осознания вещно-предметного мира как ценности. Поскольку меняется способ деятельно- сти и иррационально-религиозное сознание становится доминирующим - образ человека теперь задается сверхприродным актом божественного творения. Этический идеал главным своим содержанием теперь имеет духовную устремленность, добро и благо понимаются как сохранение божественного образа и бессмертной души посредством соответствующей деятельности. Образ человека-героя и атлета сменяется образом человекастрадальца и аскета. Соответственно эстетический идеал предстает как выражение высокой духовности, устремления к божественному совершенству. Ментальность такого типа культуры проникнута религиозностью и признанием приоритетности духовных видов деятельности. Комментирование, назидательность, поучение - главные среди них. Правда, этот идеал духовности настолько высок и настолько удален от грубого содержания непосредственной повседневной жизнедеятельности городского и сельского жителя, что в общем и не воспринимается как практическая цель в воспроизводстве человека. Поэтому такое важное место в культуре занимают празднества, гулянья, карнавалы, позволяющие человеку выйти пусть в условное, но свободное пространство культурной самодеятельности.

Эпоха буржуазных социальных и научно-технических революций сопряжена и с революцией культурной, то есть с совершенной переменой в понимании того, каким должен быть образ «настоящего» человека. Здесь человек - это субъект деятельности, направленной на достижение индивидуального, а значит, и социального успеха. Человек как индивидуальность - активная, инициативная, полагающаяся, прежде всего, на самого себя; это - субъект познания и творчества. Необходимость новаторской деятельности возникает во всех сферах общественной жизни: экономической, политической, социальной и духовной. Поэтому содержанием этического идеала становится общественная польза, гуманность и справедливость. Эстетический же идеал воплощает в себе представления о свободном в своей деятельности человеке, освоившем достижения культуры.

Ментальность обретает в качестве доминанты рациональные методы и содержание, но утрачивает тот целостный характер, что был присущ ментальности религиозно-духовной. Религиозное видение и понимание мира потесняется и уступает пониманию рациональному — научно-аналитическому и политико-идеологическому. Единство бытия распадается на составляющие части и воссоздается теперь как бы активной духовной деятельностью субъекта.

Тот период завершения данного типа культуры, который теперь принято называть постиндустриальным и который, как уже подчеркивалось, обнаруживает свою кризисность, существенно меняет содержание общественного идеала и его составляющих. Специализация и профессионализация деятельности привела к фрагментарности мышления как индивидуального, так и социально-группового. Такое его состояние усугубилось современным способом распространения информации, ее содержанием и структурой. В нынешних условиях прак- 
тически нет доминантных, руководящих идей для общественного сознания, а следовательно, нет и доминантных направлений и ориентиров для индивидуальной и общественной деятельности.

То есть любой фрагмент бытия (деятельности, предметности, отношений и т. д.) независимо от его объективной значимости может быть выключен из внимания или, наоборот, подан как доминантный и в качестве такового воспринят. Многое теперь зависит от того, кто такие механизмы запускает и контролирует. Возникает парадоксальное культурное пространство, в котором наиболее несамостоятельным и манипулируемым становится субъект культуры с наивысшими творческими потенциями, но его же деятельностью и взламывается этот тупик.

Ценности легко фальсифицируются, и потому наиболее важным оказывается, или кажется, собственное индивидуальное переживание бытия. Этический и эстетический идеалы становятся довольно размытыми и представляют собой некую компиляцию из образцов прежних типов культуры, объединяемых некоторыми общими принципами гуманизма в индивидуальной интерпретации, зависимой от уровня и качества воспитания, образования и характера культурной среды живущего индивида. Ментальность этого кризисного периода очень зыбкая и формируется на основе произвольной смеси научных знаний, религиозности, мистики и мифологии. В современной литературе и искусстве это состояние получило название постмодернизма, но оно характерно для всего общества в целом, проявляет себя во всех сферах. Движение мысли и деятельности осуществляется преимущественно как движение от частного к частному, а это бесконечное и в общем бесплодное движение.

Каковы же перспективы перехода к новому типу культуры?

Они связаны прежде всего с разрешением тех противоречий, которые возникли из потребительского отношения к природе и из профессионального способа деятельности. А это значит, что такие перспективы откроются раньше, чем будет выработан общественный идеал нового типа общности.

B XX веке ситуация в этом отношении была даже несколько лучше - для значительной части людей роль общественного идеала эпохи мог играть социалистический идеал. На рубеже веков его гуманистическая и социально-творческая потенция значительно снизилась, и он перестал выполнять миссию руководящей идеи в современном мире. Вполне возможно, что мир ожидает ренессанс социализма, но даже если он и будет иметь место, то, вероятно, на основе качественно иного понимания социалистической идеи. В начале XXI века такая тенденция пока не обнаруживается. Скорее всего, общественный идеал будет формироваться в направлении нового понимания гуманизма. Возможно, именно в этом направлении движется так называемый неогуманизм, идеи которого развиваются в общем привычном пространстве либерализма и неолиберализма.

Говоря о неогуманизме, его адепты имеют в виду, что в центр миропонимания надо ставить не индивидуаль- ность человека, а биосистему; что нужно отказаться от эгоистического индивидуализма, заменить его заботой о гражданском обществе и планетарной системе жизни, заботой о каждой культуре. Эти идеи совсем не плохи по содержанию, их необходимо пропагандировать, но они являются реформистскими, не пассионарными идеями.

Формирование нового общественного идеала, естественно, ведет за собой качественное изменение этического и эстетического идеалов. Первый необходимо должен воплощать в себе представление о всеобщем благе (что в настоящее время пытаются достичь опять же реформистскими усилиями оживления и обновления религий). Второй, очевидно, должен представить образ человека нового типа деятельности и нового типа мышления. Относительно успешно работает в этом направлении только разве что художественно-фантастическая литература, но не она вырабатывает общественные идеалы исторической эпохи.

Ментальность нового типа культуры должна характеризоваться системной целостностью мироощущения, мировосприятия и миропонимания, в которых осознается взаимосвязь, единство человеческой деятельности и ее результатов как в историческом, так и в региональном и в общемировом пространстве и масштабе.

Можно заметить также основные тенденции в изменении доминантных ценностей, которые выдвигает всякая культура и которыми определяется всякая культура. Ценность - смыслообразующий и структурообразующий факторы культуры, матрица, по которой осуществляется процесс ее воспроизводства. Для доцивилизационных форм культуры такой матрицей являлся племенной этнос, его сохранение и воспроизводство, и этой задаче подчинены все наличествовавшие элементы и части структуры культуры.

В цивилизационных типах культуры роль матрицы играет, скорее, тип социальной организации. XX век, не отрицая матричной роли социальной организации (государства, церкви, школы), поставил все же под сомнение ее бесспорность и выдвинул идею приоритета личности, что обусловлено как распространением гуманистических идеалов и гуманистического мышления, так и кризисным состоянием этих самых социальных организаций, их хронической неспособностью консолидировать общество.

Однако признание личности доминантной ценностью характерно для так называемого западного типа культурного развития постиндустриального общества, точнее, для той части человечества, которая может быть отнесена к этому типу. Для большей же части людей и сегодня характерны различные формы традиционных для цивилизации типов культуры. А в них доминантные ценности не только весьма разнообразны, но и противоречивы: этнос, клан, община, нация, чаще всего сопряженные с определенной религией и идеологией.

Углубляющиеся процессы глобализации (панмировая экспансия определенного способа отношения к природе, способа деятельности, мышления и понимания), с одной стороны, снижают и нивелируют указанное многообразие 
культур, с другой стороны, в значительной мере способствуют их сохранению и укреплению, поскольку заставляют их субъектов мобилизовать силы для противостояния и противодействия этим процессам. Результат этого глубокого противоречия переходной эпохи пока трудно предсказать, несмотря на, казалось бы, очевидную мощь глобализации.

Ей противодействуют весьма сильные процессы регионализации, субъекты которых все чаще обращаются к национальным и религиозным идеологиям в поисках своего обоснования. Однако кроме традиционализма и «возврата к истокам» здесь ничего не предлагается, и не надо быть особенно проницательным, чтобы понимать бесплодность для сохранения и развития культуры консервирования ее прошлых форм. Тем не менее, в нынешних, зачастую катастрофических условиях, некоторые сообщества склонны к поддержке таких «возвратных» программ.

Другое направление противодействия - модернизация, содержание которой представляется как возможность нации, приложив усилия, подняться до уровня достижений современной цивилизации (имеется в виду, конечно, западного типа) и, тем самым, сохранить свою самостоятельность и самобытность. Модернизация, если она успешно проведена, в самом деле значительно повышает возможности сохранения и подъема культуры, но не меняет ее типа. Наконец, глобализации противостоят различные общественные организации и движения, побуждаемые, так сказать, «общечеловеческими» ценностями гуманистического, экологического или альтруистического порядка. Все это больше выражает бесплодное коловращение современной культуры и ее системный кризис, чем показывает пути к его разрешению.

В заключение заметим, что построенная схема может быть представлена как трехмерная модель культурного пространства, поскольку более или менее явно указывает способы и границы актуализации человека. Эта модель применима не только для анализа и понимания исторически масштабного (например, национального) культурного пространства, но и для анализа локальных культур и субкультур (региональных, этнонациональных, маргинальных). Разумеется, при этом надо по возможности четко определять не только границы пространств культур (субкультур), но и их соотношение (генетическое, содержательное и ценностное) с общенациональным и общемировым культурным процессом.

\section{Список литературы}

1. Сараф М.Я. Опыт типологии культуры. - Краснодар; Голицыно, 2003.

УДК 008

ББК 71.0

\section{А.В. ВОЛОШИНОВ, М.С. КУЗЬМИНА}

\section{ДИНАМИКА СИММЕТРИЙНЫХ ПАТТЕРНОВ В ТОВАРНЫХ ЗНАКАХ РОССИИ $X X-X X I B E K O B$}

Рассматривается феномен симметрии как одна из основополагающих формообразующих характеристик геометрического модуля товарных знаков, отражающая развитие дизайна и графической культуры в целом. Выделены оптимальные хронологические периоды для контент-анализа рисунка товарных знаков. Установлена взаимосвязь динамики симметрийных паттернов товарных знаков с общими тенденциями развития культуры России.

Ключевые слова: товарный знак, логотип, симметрия, паттерн, дизайн.

$\mathrm{B}$ ыдающаяся, если не сказать основополагающая, формообразующая роль - симметрии в природе сегодня общеизвестна. Господство законов симметрии простирается от макрокосмоса симметрии подобия спиральных галактик и центрально-симметричной Солнечной системы, через билатеральную симметрию подвижных животных и поворотную симметрию неподвижных растений вплоть до симметрии микромира кристаллических решеток, двойной спирали молекулы ДНК и атомного ядра. Чем больше мы узнаем о роли симметрии в морфологии мироздания, тем сильнее завораживает всемогущество ее законов, воплощающих один из центральных принципов природы принцип единства в многообразии. Этот священный трепет перед законами симметрии природы звучит в Нобелевской лекции американского физика Чжень-нин Янга: «Чувство глубочайшего уважения к мощи законов симметрии никогда не ослабевает у того, кто обдумывает изящество и красоту безупречных математических доказательств и сопоставляет это со сложными и далеко идущими физическими и философскими следствиями» $[1$, с. 80]. 